\title{
PELAKSANAAN PEMUNGUTAN PAJAK HOTEL DAN KONTRIBUSINYA TERHADAP PENDAPATAN ASLI DAERAH DI KOTA BANDAR LAMPUNG
}

\author{
Nurmayani \\ Dosen dan Ketua Bagian Hukum Administrasi Negara Fak. Hukum Unila
}

\begin{abstract}
Abstrak
Perda Kota Bandar Lampung Nomor 07 Tahun 2002 tentang Pajak Hotel dalam pelaksanaannya masih ada hambatan. Oleh karena itu diteliti mengenai aturan dan pelaksanaannya.Penelitian ini adalah penelitian hukum normatif (Dogmati Research). Pendekatan masalahnya menggunakan pendekatanperaturan perundang-undangan (Statue Approach). Hasil Penelitian menunjukkan terdapat ketidaksinkronan pengaturan mengenai pajak hotel dalam Peraturan Daerah Kota Bandar Lampung Nomor 07 Tahun 2002 dengan Undang-Undang Nomor 28 Tahun 2009 tentang Pajak dan Retribusi Daerah.
\end{abstract}

Kata Kunci : Pajak hotel, konstribusi dan Pendapatan asli daerah.

\section{PENDAHULUAN}

Pajak daerah merupakan salah satu bentuk pungutan oleh negara kepada rakyat, oleh karena itu Pasal 23A UUD NRI Tahun 1945 mengatur bahwa "Pajak dan pungutan lain yang bersifat memaksa untuk keperluan negara diatur dengan undang-undang”. Berdasarkan ketentuan ini, maka setiap pungutan yang bersifat memaksa diatur dengan undangundang. Kewenangan untuk mengenakan pungutan bukan sekedar sebagai sumber pendapatan, tetapi sekaligus melambangkan kebebasan untuk menentukan diri sendiri secara mengatur dan mengurus rumah tangga daerah yang bersangkutan (Bagir Manan, 2001 : 204). Kewenangan pemungutan pajak harus dilakukan secara bertanggungjawab dan berdasarkan hukum untuk meningkatkan Peningkatan Pendapatan Asli Daerah yang harus ditujukan untuk pembiayaan pelayanan kepada masyarakat.

Peningkatan Pendapatan Asli Daerah (PAD) disamping untuk meningkatkan kemampuan pembiayaan Pemerintah Daerah juga untuk mengurangi ketergantungan daerah kepada pusat. Upaya meningkatkan pendapatan asli daerah dapat dicapai dengan mengoptimalkan penerimaan pendapatan asli daerah melalui peningkatan kinerja aparatur pengelola pungutan PAD maupun penerapan aspek teknis pemungutan secara proporsional dan prefesional. Disisi lain dalam upaya peningkatan PAD khususnya pajak daerah melalui intensifikasi perlu didukung data yang akurat, aarana prasarana, sumber daya manusia yang memadai, sistem serta penyiapan penanganan pajak yang handal, transparan, dapat dipertanggungjawabkan, terwujudnya pelayanan prima serta partisipasi aktif dari semua elemen masyarakat. 
Berdasarkan Undang-Undang No 34 Tahun 2000 tentang Pajak Retrebusi Daerah, yang telah dinyatakan tidak berlaku lagi dengan Undang-Undang Nomor 28 Tahun 2009, jenis-jenis pajak kabupaten/ kota adalah sebagai berikut: Pajak Hotel, Restoran, Hiburan, Reklame, Penerangan Jalan, pengambilan Bahan Galian Golongan C, Parkir, PBB Perkotaan dan Pedesaan, Bea Perolehan Atas Tanah Dan Bangunan, Pajak Sarang Burung Walet, Pajak Pengambilan dan Pemanfaatan Air Bawah Tanah

Salah satu jenis pajak daerah Kota Bandar Lampung yang mempunyai potensi cukup besar adalah Pajak Hotel yang diatur dalam Peraturan Daerah Kota Bandar Lampung Nomor 7 Tahun 2002. Dari data yang diperoleh diketahui bahwa target penerimaan Pajak Hotel Rp 4.800.000.000,- dan realisasinya $\mathrm{Rp}$. 4.818.205.223,-- meskipun penerimaan pajak hotel melampaui target yang ditentukan bukan berarti telah optimal, jika dikaitkan dengan melihat perkembangan usaha hotel yang ada di Kota Bandar Lampung, maka kemungkinan masih banyak potensi yang belum tergali. Di sisi lain kurangnya kesadaran mayarakat, pemungutan pajak yang tidak transparan juga menyebabkan penerimaan pajak hotel yang kurang optimal. Untuk itu, peneliti tertarik untuk meneliti tentang pengaturan pelaksanaan pemungutan pajak hotel di Kota Bandar Lampung dan Kontribusinya terhadap PAD Kota Bandar Lampung.

Berdasarkan uraian di atas maka permasalahan dalam penelitian ini adalah:
a. Bagaimanakah
Pengaturan tentang Pajak Hotel di Kota Bandar lampung?

b. Bagaimanakah Pelaksanan Pemungutan Pajak Hotel dan Kontribusinya terhadap PAD Kota Bandar Lampung?

\section{PEMBAHASAN}

\subsection{Kajian Normatif Pengaturan Pajak Hotel}

Setiap jenis pajak daerah yang diberlakukan di Indonesia harus mempunyai dasar hukum yang kuat untuk menjamin kelancaran pengenaan dan pemungutannya. Sesuai dalam penjelasan Pasal 23 ayat (2) Undang-Undang Dasar Negara RI 1945 sebelum amandemen ditegaskan, bahwa penetapan belanja mengenai hak rakyat untuk menentukan nasibnya sendiri, maka segala tindakan yang menempatkan beban kepada rakyat, seperti pajak dan lain-lainnya, harus ditetapkan dengan undang-undang, yaitu dengan persetujuan Dewan Perwakilan Rakyat. Oleh karena itu pemungutan pajak daerah dan retribusi daerah harus didasarkan undang-undang. Tidak terkecuali pajak hotel sebagai salah satu jenis pajak daerah.

Berdasarkan Pasal 1 Angka 20 Undang-Undang Nomor 28 Tahun 2009 tentang Pajak Daerah dan Retribusi Daerah, yang dimaksud Pajak Hotel adalah pajak atas pelayanan yang disediakan oleh hotel. Kewenangan pemungutan pajak hotel ada pada pemerintah kabupaten/kota, untuk itu dalam melakukan pemungutan pajak hotel harus didasarkan pada peraturan daerah. Pemungutan Pajak Hotel di Kota Bandar Lampung didasarkan pada Peraturan Daerah Kota Bandar Lampung Nomor 07 Tahun 2002 tentang Pajak Hotel. 
Tabel 3.

Perbandingan Pengaturan Pajak Hotel

\begin{tabular}{|c|c|c|}
\hline Pengaturan & $\begin{array}{c}\text { Undang-Undang Nomor } 28 \\
\text { Tahun } 2009 \text { tentang } \\
\text { Pajak Daerah } \\
\text { dan Retribusi Daerah }\end{array}$ & $\begin{array}{c}\text { Peraturan Daerah Kota } \\
\text { Bandar Lampung Nomor } 07 \\
\text { Tahun } 2002 \text { tentang } \\
\text { Pajak Hotel }\end{array}$ \\
\hline Definisi & $\begin{array}{l}\text { Hotel adalah fasilitas penyedia } \\
\text { jasa penginapan/peristirahatan } \\
\text { termasuk jasa terkait lainnya } \\
\text { dengan dipungut bayaran, yang } \\
\text { mencakup juga motel, losmen, } \\
\text { gubuk pariwisata, wisma } \\
\text { pariwisata, pesanggrahan, } \\
\text { rumah penginapan dan } \\
\text { sejenisnya, serta rumah kos } \\
\text { dengan jumlah kamar lebih } \\
\text { dari } 10 \text { (sepuluh). }\end{array}$ & $\begin{array}{l}\text { Hotel adalah bangunan yang } \\
\text { khusus disediakan bagi orang } \\
\text { untuk dapat menginap/istirahat, } \\
\text { memperoleh pelayanan dan } \\
\text { atau fasilitas lainnya dengan } \\
\text { dipungut bayaran, termasuk } \\
\text { bangunan lainnya yang } \\
\text { menyatu, dikelola dan dimiliki } \\
\text { oleh pihak yang sama kecuali } \\
\text { untuk Pertahanan dan } \\
\text { Perkantoran. }\end{array}$ \\
\hline Objek & $\begin{array}{l}\text { Objek Pajak Hotel adalah } \\
\text { pelayanan yang disediakan oleh } \\
\text { Hotel dengan pembayaran, } \\
\text { termasuk jasa penunjang } \\
\text { sebagai kelengkapan Hotel yang } \\
\text { sifatnya memberikan } \\
\text { kemudahan dan kenyamanan, } \\
\text { termasuk fasilitas olahraga dan } \\
\text { hiburan. } \\
\text { Yang dimaksud jasa penunjang } \\
\text { adalah: fasilitas telepon, } \\
\text { faksimile, teleks, internet, } \\
\text { fotokopi, pelayanan cuci, } \\
\text { seterika, transportasi, dan } \\
\text { fasilitas sejenis lainnya yang } \\
\text { disediakan atau dikelola Hotel. } \\
\text { Tidak termasuk objek Pajak } \\
\text { Hotel adalah: } \\
\text { a. jasa tempat tinggal asrama } \\
\text { yang diselenggarakan oleh } \\
\text { Pemerintah atau } \\
\text { Pemerintah Daerah; } \\
\text { b. jasa sewa apartemen, } \\
\text { kondominium, dan } \\
\text { sejenisnya; } \\
\text { c. jasa tempat tinggal di pusat } \\
\text { pendidikan atau kegiatan } \\
\text { keagamaan; }\end{array}$ & $\begin{array}{l}\text { Obyek Pajak Hotel adalah } \\
\text { setiap pelayanan yang } \\
\text { disediakan Hotel dengan } \\
\text { pembayaran termasuk: } \\
\text { a. Fasilitas penginapan atau } \\
\text { fasilitas tinggal jangka } \\
\text { pendek; } \\
\text { b. Pelayanan penunjang } \\
\text { sebagai kelengkapan } \\
\text { fasilitas penginapan atau } \\
\text { tinggal jangka pendek yang } \\
\text { sifatnya memberikan } \\
\text { kemudahan dan } \\
\text { kenyamanan; } \\
\text { c. Fasilitas olah raga dan } \\
\text { hiburan yang disediakan } \\
\text { khusus oleh hotel; } \\
\text { d. Jasa persewaan ruangan } \\
\text { untuk kegiatan acara atau } \\
\text { pertemuan di hotel. } \\
\text { Tidak termasuk Obyek Pajak } \\
\text { adalah: } \\
\text { a. Penyewaan rumah atau } \\
\text { kamar, apartemen dan atau } \\
\text { fasilitas tempat tinggal } \\
\text { lainnya yang tidak menyatu } \\
\text { dengan hotel; } \\
\text { b. Pelayanan tinggal di asrama } \\
\text { dan di Pondok Pesantren; }\end{array}$ \\
\hline
\end{tabular}




\begin{tabular}{|c|c|c|}
\hline & $\begin{array}{l}\text { d. } \text { jasa tempat tinggal di } \\
\text { rumah sakit, asrama } \\
\text { perawat, panti jompo, panti } \\
\text { asuhan, dan panti sosial } \\
\text { lainnya yang sejenis; dan } \\
\text { e. jasa biro perjalanan atau } \\
\text { perjalanan wisata yang } \\
\text { diselenggarakan oleh Hotel } \\
\text { yang dapat dimanfaatkan } \\
\text { oleh umum. }\end{array}$ & $\begin{array}{l}\text { c. Fasilitas olahraga dan } \\
\text { hiburan yang disediakan di } \\
\text { hotel yang dipergunakan } \\
\text { oleh bukan tamu hotel } \\
\text { dengan pembayaran; } \\
\text { d. Pertokoan, Perkantoran, } \\
\text { Perbankan, salon yang } \\
\text { dipergunakan oleh umum di } \\
\text { Hotel; } \\
\text { e. Pelayanan perjalanan wisata } \\
\text { yang diselenggarakan oleh } \\
\text { hotel dan dapat } \\
\text { dimanfaatkan oleh umum. }\end{array}$ \\
\hline Subjek & $\begin{array}{l}\text { a. Subjek Pajak Hotel adalah } \\
\text { orang pribadi atau Badan } \\
\text { yang melakukan } \\
\text { pembayaran kepada orang } \\
\text { pribadi atau Badan yang } \\
\text { mengusahakan Hotel. } \\
\text { b. Wajib Pajak Hotel adalah } \\
\text { orang pribadi atau Badan } \\
\text { yang mengusahakan Hotel. }\end{array}$ & $\begin{array}{l}\text { a. Subyek pajak hotel adalah } \\
\text { orang pribadi atau badan } \\
\text { yang melakukan } \\
\text { pembayaran kepada hotel. } \\
\text { b. Wajib Pajak Hotel adalah } \\
\text { pengusaha hotel. }\end{array}$ \\
\hline Tarif & $\begin{array}{l}\text { Tarif Pajak Hotel ditetapkan } \\
\text { paling tinggi sebesar } 10 \% \\
\text { (sepuluh persen). }\end{array}$ & $\begin{array}{l}\text { Tarif Pajak ditetapkan sebesar } \\
10 \% \text { (sepuluh perseratus). }\end{array}$ \\
\hline
\end{tabular}

Dari pengaturan diatas dapat dilihat perbedaan-perbedaan pengaturan mengenai pajak hotel dalam Undang-Undang Nomor 28 Tahun 2009 tentang Pajak Daerah dan Retribusi Daerah dengan Peraturan Daerah Kota Bandar Lampung Nomor 07 Tahun 2002 tentang Pajak Hotel. Perbedaan tersebut dapat dilihat pada aspek definisi, objek, subjek dan tarif. Pada aspek definisi, Undang-Undang Nomor 28 Tahun 2009 merinci cakupan hotel termasuk juga motel, losmen, gubuk pariwisata, wisma pariwisata, pesanggrahan, rumah penginapan dan sejenisnya, serta rumah kos dengan jumlah kamar lebih dari 10 (sepuluh). Sementara Perda Nomor 07 Tahun 2002 hanya memaparkan secara umum mengenai hotel dan memberikan pengecualian yaitu bangunan yang dikelola dan dimiliki oleh pihak untuk keperluan Pertahanan dan Perkantoran. Begitu juga dengan aspek objek dan subjek, Undang-Undang Nomor 28 Tahun 2009 lebih jelas pengaturannya dibandingkan Perda Nomor 07 Tahun 2002. Sementara dari aspek tarif, Undang-Undang Nomor 28 Tahun 2009 telah menentukan tarif maksimal sebesar 10\%. Besaran tarif tersebut juga diakomodir oleh Perda Nomor 07 Tahun 2002 dengan menetapkan tarif pajak hotel sebesar $10 \%$.

Dari perbandingan pengaturan tersebut diatas, terdapat beberapa ketentuan yang tidak sinkron antara Undang-Undang Nomor 28 Tahun 2009 tentang Pajak Daerah dan Retribusi Daerah dengan Peraturan Daerah Kota Bandar Lampung 
Nomor 07 Tahun 2002 tentang Pajak Hotel. Dengan begitu, seharusnya dilakukan perubahan terhadap Peraturan Daerah Kota Bandar Lampung Nomor 07 Tahun 2002 tentang Pajak Hotel, perubahan dilakukan untuk menyesuaikan/mensinkronisasikan materi pengaturan pajak hotel dengan ketentuan Undang-Undang Nomor 28 Tahun 2009 tentang Pajak Daerah dan Retribusi Daerah, agar pemungutan pajak hotel di Kota Bandar Lampung sesuai dengan ketentuan peraturan perundangundangan.

\subsection{Kajian \\ Pelaksanan \\ Pemungutan Pajak Hotel dan \\ Kontribusinya terhadap PAD \\ Kota Bandar Lampung}

Perolehan pajak daerah Kota Bandar Lampung terus mengalami peningkatan setiap tahunnya dengan pencapaian target yang cukup signifikan. Hal ini dapat dilihat pada tabel 4 berikut ini :

Tabel 4.

Perkembangan Pajak Daerah Kota Bandar Lampung Tahun 2008-2010

\begin{tabular}{|c|c|c|c|}
\hline Tahun & Target (Rp) & Realisasi (Rp) & Capaian (\%) \\
\hline 2008 & 36.100 .000 .000 & 42.519 .078 .836 & 111.25 \\
\hline 2009 & 45.500 .000 .000 & 47.035 .295 .283 & 103.37 \\
\hline 2010 & 52.614 .913 .548 & 56.627 .114 .786 & 107.63 \\
\hline
\end{tabular}

Sumber: Dinas Pendapatan Daerah Kota Bandar Lampung.

Ditinjau dari Pendapatan Asli Daerah maka tingkat hunian hotel memiliki korelasi positif dengan besaran pajak hotel dan restoran. Dengan demikian perlu upaya yang lebih lebih intensif untuk kemajuan sektor ini.

Berdasarkan ketentuan Pasal 4 Peraturan Pemerintah Nomor 91 Tahun 2010 tentang Jenis Pajak Daerah yang Dipungut Berdasarkan Penetapan Kepala Daerah Atau Dibayar Sendiri Oleh Wajib Pajak. Pajak Hotel termasuk jenis pajak yang dipungut dengan cara dibayar sendiri oleh wajib pajak (self assesment system). Dengan begitu, wajib pajak membayar sendiri pajak hotel berdasarkan besaran yang telah ditetapkan dengan peraturan daerah. Pelaksanaan pemungutan pajak hotel dilakukan dengan cara wajib pajak membayar sendiri pajak hotel tersebut kepada hotel yang bersangkutan sesuai dengan tarif pajak yang telah ditetapkan pada peraturan daerah. Kemudian pihak hotel melakukan pembayaran pajak hotel pada Dinas Pendapatan Daerah Kota Bandar Lampung atas pajak yang dibayarkan oleh konsumen hotel tersebut sesuai dengan pembukuan pendapatan hotel. Mekanisme pembayaran tersebut dapat dilihat pada bagan dibawah ini. 
Bagan 1.

Alur Pemungutan Pajak Hotel

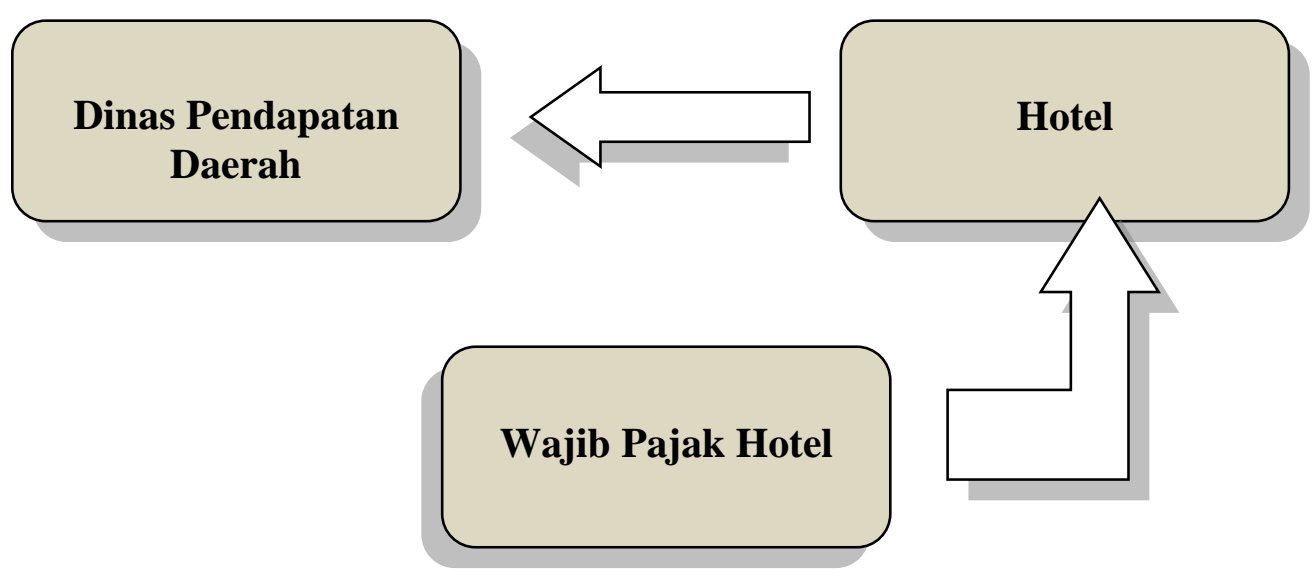

Pemungutan Pajak Hotel yang didasarkan pada Peraturan Daerah Kota Bandar Lampung Nomor 07 Tahun 2002 tidak sinkron dengan Peraturan Pemerintah Nomor 91 Tahun 2010 tentang Jenis Pajak Daerah yang Dipungut Berdasarkan Penetapan Kepala Daerah Atau Dibayar Sendiri Oleh Wajib Pajak. Karena pada Pasal 14 Peraturan Daerah Nomor 07 Tahun 2002 mengatur Pembayaran Pajak dilakukan di Kas Daerah dengan menggunakan Surat Ketetapan Pajak
Daerah yang merupakan dasar pembayaran pajak berdasarkan penetapan kepala daerah. Seharusnya, sesuai dengan ketentuan Pasal 6 ayat (3) Peraturan Pemerintah Nomor 91 Tahun 2010, pemungutan pajak terutang dengan cara dibayar sendiri oleh Wajib Pajak didasarkan pada Surat Pemberitahuan Pajak Daerah. Untuk itu perlu dilakukan perubahan materi perda tersebut agar pengaturannya sinkron dengan peraturan perundang-undangan yang lebih tinggi.

Tabel 6.

Kontribusi Pajak Hotel Terhadap PAD Kota Bandar Lampung

\begin{tabular}{|c|c|c|c|c|r|r|}
\hline No & Thn & Target & Realisasi & PAD & $\%$ & $\begin{array}{c}\text { Sisa Lebih } \\
\text { (Kurang) } \\
\text { Anggaran }\end{array}$ \\
\hline 1 & 2008 & 4.800 .000 .000 & 4.818 .205 .223 & 36.100 .000 .000 & 13,5 & 18.205 .223 \\
\hline 2 & 2009 & 5.100 .000 .000 & 5.139 .059 .982 & 72.009 .309 .841 & 7,5 & 39.059 .982 \\
\hline 3 & 2010 & 5.954 .342 .000 & 6.660 .451 .524 & 84.167 .470 .269 & 8 & 706.109 .524 \\
\hline
\end{tabular}

Sumber: Dinas Pendapatan Daerah Kota Bandar Lampung.

Berdasarkan data diatas, dapat dilihat kontribusi pajak hotel terhadap pendapatan asli daerah Kota Bandar Lampung selama tiga tahun sejak tahun 2008-2010. Kontribusi pajak hotel terhadap pendapatan asli daerah Kota Bandar Lampung selama tiga tahun berturut-turut 
hanya kurang dari 15\%. Hal ini sudah cukup baik, namun perlu lebih dioptimalkan lagi. Untuk itu perlu dilakukan optimalisasi pemungutan pajak hotel dengan metode intensifikasi.

Secara umum, upaya yang perlu dilakukan oleh Pemerintah Daerah dalam rangka meningkatkan pendapatan daerah melalui optimalisasi intensifikasi pemungutan pajak daerah dan retribusi daerah, antara lain dapat dilakukan dengan cara-cara sebagai berikut:

a. Memperkuat proses pemungutan. Upaya yang dilakukan dalam memperkuat proses pemungutan, yaitu antara lain mempercepat penyusunan peraturan daerah, melakukan penyesuaian tarif dengan kondisi pemungutan pajak, dan meningkatkan SDM.

b. Meningkatkan pengawasan. Hal ini dapat ditingkatkan yaitu antara lain dengan melakukan pemeriksaan secara dadakan dan berkala, memperbaiki proses pengawasan, menerapkan sanksi terhadap penunggak pajak dan sanksi terhadap pihak fiskus, serta meningkatkan pembayaran pajak dan pelayanan yang diberikan oleh daerah.

c. Meningkatkan efisiensi administrasi dan menekan biaya pemungutan. Tindakan yang dilakukan oleh daerah yaitu antara lain memperbaiki prosedur administrasi pajak melalui penyederhanaan administrasi pajak, meningkatkan efisiensi pemungutan dari setiap jenis pemungutan.

d. Meningkatkan kapasitas penerimaan melalui perencanaan yang lebih baik. Hal ini dapat dilakukan dengan meningkatkan koordinasi dengan instansi terkait pemungutan pajak daerah. Optimalisasi intensifikasi pemungutan pajak tersebut dapat juga dilakukan dalam pemungutan pajak hotel.

\section{PENUTUP}

\subsection{Simpulan}

a. Pemungutan Pajak Hotel di Kota Bandar Lampung didasarkan pada Peraturan Daerah Kota Bandar Lampung Nomor 07 Tahun 2002 tentang Pajak Hotel. Terdapat ketidaksinkronan pengaturan mengenai pajak hotel dalam Peraturan Daerah Kota Bandar Lampung Nomor 07 Tahun 2002 tentang Pajak Hotel dengan Undang-Undang Nomor 28 Tahun 2009 tentang Pajak Daerah dan Retribusi Daerah. Hal tersebut dapat dilihat pada aspek definisi, objek, subjek dan tarif.

b. Peraturan Daerah Nomor 07 Tahun 2002 tentang Pajak Hotel mengatur Pembayaran Pajak dilakukan di Kas Daerah dengan menggunakan Surat Ketetapan Pajak Daerah (menggunakan official asesment system). Seharusnya, sesuai dengan ketentuan Pasal 6 ayat (3) Peraturan Pemerintah Nomor 91 Tahun 2010, pemungutan pajak hotel didasarkan pada Surat Pemberitahuan Pajak Daerah (menggunakan self asesment system). Kontribusi pajak hotel terhadap pendapatan asli daerah Kota Bandar Lampung selama tiga tahun berturut-turut hanya kurang dari $15 \%$. Hal ini sudah cukup baik, namun perlu lebih dioptimalkan lagi.. 


\subsection{Saran}

a. Harus dilakukan perubahan terhadap Peraturan Daerah Kota Bandar Lampung Nomor 07 Tahun 2002 tentang Pajak Hotel, perubahan dilakukan untuk menyesuaikan/mensinkronisasika $\mathrm{n}$ materi pengaturan pajak hotel dengan ketentuan UndangUndang Nomor 28 Tahun 2009 tentang Pajak Daerah dan Retribusi Daerah dan Peraturan Pemerintah Nomor 91 Tahun 2010 tentang Jenis Pajak Daerah yang Dipungut Berdasarkan Penetapan Kepala Daerah Atau Dibayar Sendiri Oleh Wajib Pajak. Agar pemungutan pajak hotel di Kota Bandar Lampung sesuai dengan ketentuan peraturan perundangundangan.

b. Perlu dilakukan optimalisasi intensifikasi pemungutan pajak hotel dengan cara: memperkuat proses pemungutan, meningkatkan pengawasan, meningkatkan efisiensi administrasi dan menekan biaya pemungutan, dan meningkatkan kapasitas penerimaan melalui perencanaan yang lebih baik.

\section{DAFTAR PUSTAKA}

Atmosudirjo, Prajudi. 1994. Hukum Administrasi Negara. Ghalia Indonesia. Jakarta.

Boediono. 2001. Perpajakan Indonesia. Penerbit Diadi Media. Jakarta.

Bruton, Richard, B. Ilyas, Wirawan. 2001. Hukum Pajak. Penerbit PT. Salemba Emban Patria. Jakarta.
Darise, Nurlan. 2007. Pengelolaan Keuangan Daerah. Penerbit PT. Indeks. Jakarta.

Davey, K.J. 1988. Pembiayaan Pemerintah Daerah. Penerbit Universitas Indonesia. Jakarta.

Hadjon, Philipus Mandiri, et all. 1994. Pengantar Hukum Administrasi Indonesia. Gajah Mada University Press.

Ilyas, Wirawan B. \& Richard Burton, 2007. Hukum Pajak Edisi 3, Salemba Empat, Jakarta.

Muhammad, Abdulkadir. 2004. Hukum dan Penelitian Hukum. PT. Citra Aditya Bakti. Bandung.

Mardiasmo. 2003. Perpajakan. Penerbit Andi Offiset. Yogyakarta.

Siahaan, Marihot P. 2005. Pajak Daerah dan Retrebusi Daerah. PT. Raja Grafindo Persada. Jakarta.

Slamet, Margono. 1997. Mahasiswa Dalam Membangun. Universitas Lampung. Press : Bandar Lampung.

Soemitro, Rochmat. 1991. Asas dan Dasar Perpajakan I, PT. Eresco, Bandung.

Ridwan, HR. 2006. Hukum Administrasi Negara. Raja Grafindo Persada. Jakarta.

Riwu Kaho, Josef. 1998. Prospek Otonomi Daerah di Negara Republik Indonesia. Penerbit Rajawali Press. Jakarta.

Ronny, Tubagus Rahman Niti Baskara. 2002. Paradoksal Konflik dan Otonomi Daerah, Sketsa Bayang-Bayang Konflik 
Dalam Prospek Masa Depan Otonomi daerah.

Waluyo, Wirawan B. Ilyas. 2002.

Perpajakan Indonesia. Penerbit

PT. Salemba Emban Patria.

Jakarta.

Yuswanto. 1997. Intensifikasi dan

Ekstensifikasi Pemasukan

Pajak Daerah Di Daerah

Tingkat II Dalam Wilayah

Propinsi Daerah Tingkat I

Lampung. Universitas

Padjadjaran. Tesis. Bandung.

\section{Peraturan Perundang-Undangan}

Undang-Undang Nomor 17 Tahun 2003 tentang Keuangan Negara (lembaran Negara Republik Indonesia Tahun 2003 Nomor 47, Tambahan lembaran Negara Republik Indonesia Nomor 4286);

Undang-Undang Nomor 32 Tahun 2004 tentang Pemerintahan Daerah sebagaimana telah diubah beberapa kali terakhir dengan Undang-Undang Nomor 12 Tahun 2008 tentang Perubahan Kedua atas Undang-Undang Nomor 32 Tahun 2004 tentang Pemerintahan Daerah (Lembaran Negara Republik Indonesia Tahun 2008 Nomor 59, Tambahan Lembaran Negara Republik Indonesia Nomor 4844).

Undang-Undang Nomor 33 Tahun 2004 tentang Perimbangan Keuangan Antara Pemerintah Pusat dan Pemerintahan Daerah (Lembaran Negara Republik Indonesia Tahun
2004 Nomor 126, Tambahan Lembaran Negara Republik Indonesia Nomor 1438);

Undang-Undang Nomor 28 Tahun 2009 tentang Pajak Daerah dan Retribusi Daerah (Lembaran Negara Republik Indonesia Tahun 2009 Nomor 130, Tambahan Lembaran Negara Republik Indonesia Nomor 5049);

Peraturan Pemerintah Nomor 38

Tahun 2007 tentang

Pembagian Urusan

Pemerintahan antara

Pemerintah, Pemerintahan

Daerah Provinsi dan

Pemerintahan Daerah

Kabupaten/Kabupaten

(Lembaran Negara Republik

Indonesia Tahun 2007 Nomor

82, Tambahan Lembaran

Negara Republik Indonesia Nomor 4737 ) ;

Peraturan Pemerintah Nomor 91

Tahun 2010 tentang Jenis Pajak

Daerah yang Dipungut

Berdasarkan Penetapan Kepala

Daerah Atau Dibayar Sendiri

Oleh Wajib Pajak (Lembaran

Negara Republik Indonesia

Tahun 2010 Nomor 153,

Tambahan Lembaran Negara

Republik Indonesia Nomor 5179);

Peraturan Daerah Kota Bandar Lampung Nomor 07 Tahun 2002 tentang Pajak Hotel. (Lembaran Daerah Kota Bandar Lampung Tahun 2002 Nomor 7 Seri B); 